J. clin. Path. (1948), 1, 73.

\title{
RAPID AND ECONOMICAL RHESUS TESTING : A TRIAL OF CHOWN'S CAPILLARY TUBE METHOD
}

\author{
BY \\ GEORGE DISCOMBE AND H. MEYER \\ From the Central Middlesex County Hospital
}

(RECEIVED For PUblication, DeCEMber 30, 1947)

\section{Introduction}

It is now firmly established that immunization by the Rhesus factor plays a predominant part in the pathogenesis of haemolytic disease of the newborn (Levine and others, 1941a and b), and that treatment by early induction of labour and transfusion or exsanguination transfusion will reduce the mortality of affected infants to about one quarter of that found in an untreated series (Diamond, 1947). It has also been shown that a single transfusion of Rhesus-positive blood will sensitize about half of all Rhesus-negative recipients (Moloney, 1945 ; Diamond, 1947 ; Hattersley, 1947), and that Rhesus-positive babies born to previously sensitized Rhesus-negative mothers are usually affected by a severe form of haemolytic disease. It is therefore essential to determine the Rhesus group of all female recipients of transfusions who are potential mothers, and to give only Rhesus-negative blood to Rhesus-negative recipients.

It is possible that the slide test, using the incomplete or blocking antibody (Diamond and Abelson, 1945), would be the method of choice, but unfortunately high-titre high-avidity sera of this type are not generally available in this country. Satisfactory sera derived from animals are troublesome to prepare. Sera of human origin containing the ordinary agglutinating antibody have thus to be used, but unfortunately sera with a high titre (1/32 or over), are seldom encountered, though there is less difficulty in obtaining sera with a titre of $1 / 8$ or $1 / 16$.

The standard technique, using precipitin tubes, is reliable but laborious; it also requires scrupulously clean glassware and relatively large volumes of sera. This report is concerned with a recent trial of the method of Chown (Chown and Lewis, $1944,1946)$, to which our attention was directed by Dr. Race.

\section{Method}

In Chown's technique the cells to be tested are allowed to fall through a column of agglutinating serum contained in an inclined capillary tube of 0.3 to $1.0 \mathrm{~mm}$. bore. If the cells are agglutinated they seem to become sticky and to adhere to the wall of the capillary in discrete clumps which can easily be seen by the naked eye, usually within ten minutes of starting incubation. Capillary tubes of about $0.5 \mathrm{~mm}$. $(0.3 \mathrm{~mm}$. to $1.0 \mathrm{~mm}$.) bore and about $7 \mathrm{~cm}$. in length are required. These are easily drawn from 7 to $8 \mathrm{~mm}$. diameter soft glass tubing and broken to approximate length between the fingers ; several hundred may be made in half an hour. A block of plasticine is also needed, but if a large series is to be done it is convenient to replace the plasticine by a container of soft paraffin and to employ a perspex rack or the heated rack described by Chown and Lewis (1946) to hold the capillaries. An anti-D agglutinating serum from which the anti-A and anti-B agglutinins have been absorbed is employed.

A capillary is dipped vertically into the serum until a column 10 to $20 \mathrm{~mm}$. long has entered by capillarity. It is then removed and dipped into the unknown test cell suspension until a column of about the same length has entered (care must be taken to avoid air-locks), inverted, and the lower end (which did not enter the fluids) stuck into the plasticine at an angle of about $45^{\circ}$ : or, if a rack is used, the lower end is plugged with vaseline and the capillary placed in the rack. The capillary is then incubated at $38^{\circ} \mathrm{C}$. and inspected at intervals. In about half of all Rhesus-positive samples, segmentation of the cell column will be visible in 5 to 10 minutes ; this segmentation constitutes a positive reaction (Plate $\mathrm{I} a$ ). Most positives are definite in 15 minutes, but a few develop only after about 


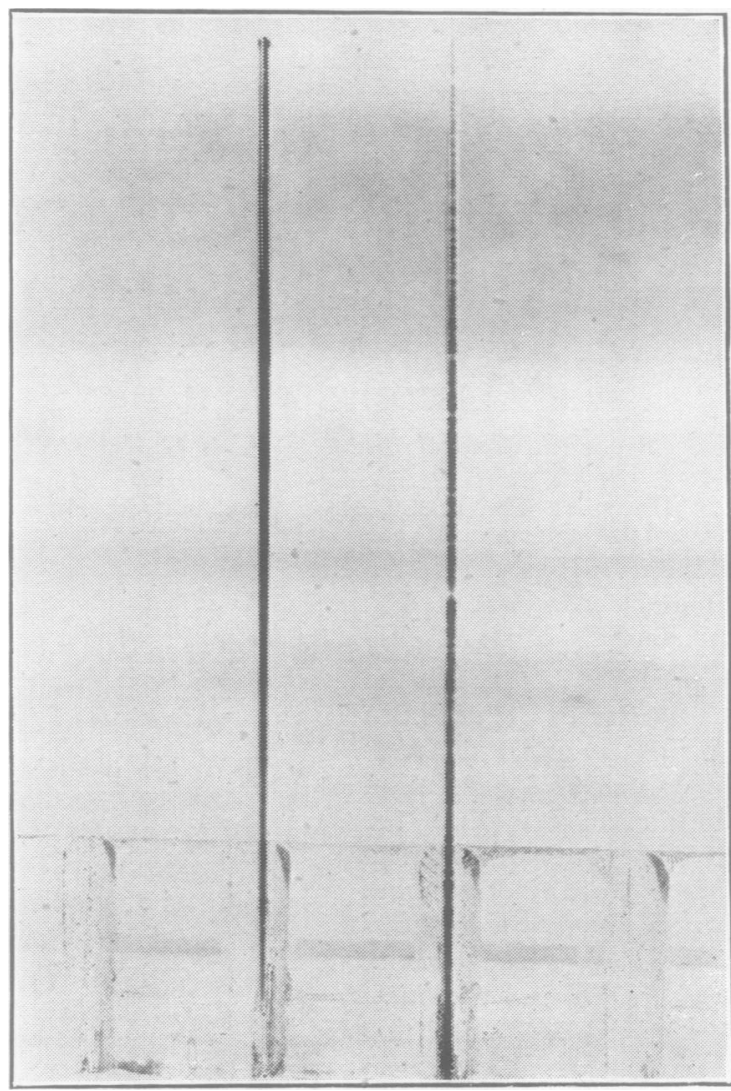

(a).-The capillary test. Left-hand tube-negative reaction. Right-hand tube-positive reaction.

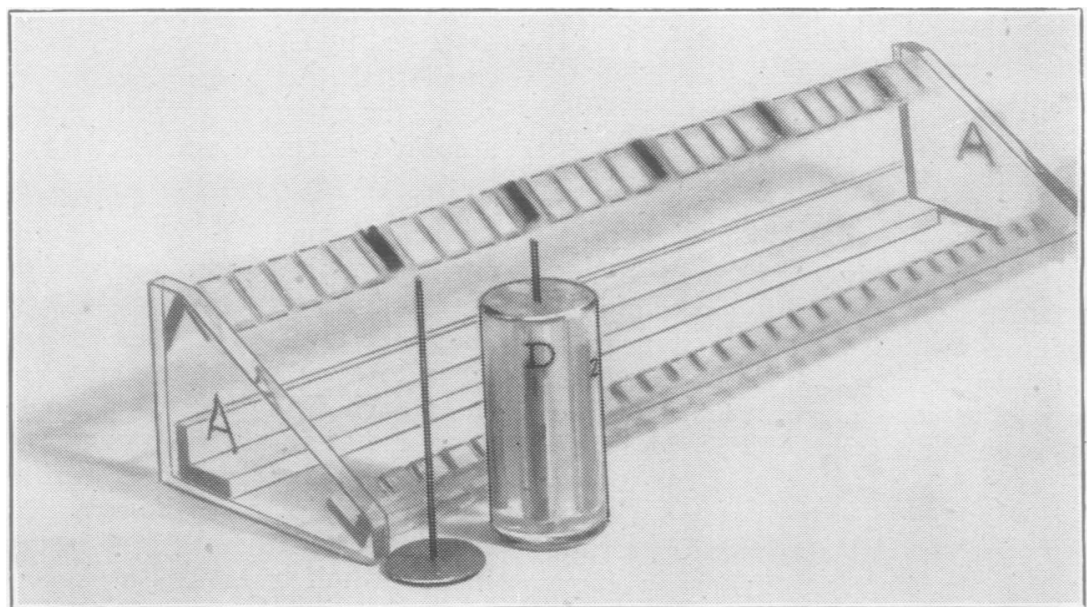

(b).-Perspex rack for tests. Polystyrene holder with handle for simultaneous washing of five samples of cells.

Plate I. 
30 minutes. A weak serum, or too dilute a cell suspension, delays the appearance of the positive reaction. If the cells are $\mathrm{R}$ hesus-negative, there is no suggestion of segmentation, the cells forming a uniform smooth layer on the lower wall of the capillary. It will be noted that in cases of urgency, where the result has to be read within a short time, an occasional Rhesus-positive blood may be misread as negative (which is of minor importance), but never Rhesus-negative blood as positive.

The strength of the cell suspension is most important. A mixture of fresh oxalated blood with once to twice its volume of isotonic citrate solution is recommended by Chown; this gives a cell suspension of about 15 per cent and is very satisfactory. However, most antenatal patients have blood taken for a Wassermann reaction. It was decided to use the residue of these samples, after the serum had been removed, by shaking the clot and the extruded cells with 1 to 2 volumes of saline. Such suspensions were found to be satisfactory, though suspensions made by removing the extruded cells by decantation, and shaking with fresh saline, were not, for they were always too dilute and frequently contained fragments of clot.

A comparison between this capillary method and the standard tube method has been made, a total of 503 specimens being examined. Of these, three were rejected owing to gross haemolysis or infection, though two proved satisfactory in the tube technique ; eight gave doubtful readings at the first trial of the capillary method, but became definite if a higher concentration of cells was used for the test ; all these eight were over six days old. Altogether, there were 399 samples positive by both methods, of which 391 were clear-cut and obvious in the capillaries, and 101 samples negative.

On the basis of this comparison, it was decided that the capillary method was suitable for routine use, subject to certain limitations ; first, the blood must be uninfected and not more than four days old ; secondly, dilute suspensions of cells must be concentrated by centrifuging and resuspension; thirdly, doubtful reactions must be checked by the tube technique. The method has now been used for some months using anti-A, anti-B, anti-D, anti-C, anti-E, anti-c and anti- $(C+D+E)$ sera, and so far the results have been unexceptionable if fresh suspensions of cells at 10 to 20 per cent concentration have been used. It has also been used to demonstrate both complete and incomplete antibodies in unknown sera, but so far insufficient experience has been gained to warrant its general adoption for the detection of antibodies, though it appears to be at least as sensitive as the tube technique. Chown (1947) informs us that in his hands it is more sensitive, and we have succeeded in obtaining clear-cut results with one batch of serum so weak that it was useless for the tube technique.

A statistical analysis of the frequency of the D-antigen in (1) the 500 samples described, (2) a series of blood donors, (3) the first 400 antenatal patients studied as a routine, and (4) a series of 2,000 cases studied by Race (1947) has been made, the four series, and some of their combinations, being analysed for homogeneity by the $\chi^{2}$ method (Tables I and II).

TABLE I

\begin{tabular}{c|c|c|c}
\hline Series & $\begin{array}{c}\text { Rhesus- } \\
\text { positive }\end{array}$ & $\begin{array}{c}\text { Rhesus- } \\
\text { negative }\end{array}$ & Total \\
\hline 1 & 399 & 101 & 500 \\
\hline 2 & 124 & 35 & 159 \\
\hline 3 & 341 & 59 & 400 \\
\hline 4 & 1,658 & 342 & 2,000 \\
\hline Total & 2,522 & 537 & 3,059 \\
\hline
\end{tabular}

TABLE II

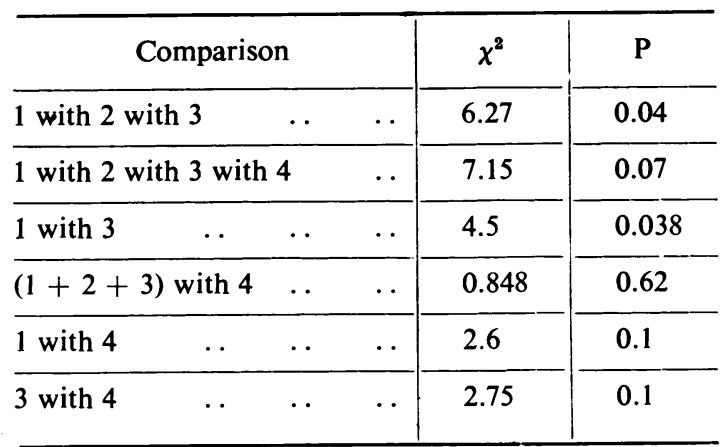

It is obvious that there is a difference of doubtful significance between the series 1 and 3 . Since all Rhesus-negative subjects are tested twice, once with anti-D and once with anti-(C+D+E) serum, while many mothers of erythroblastotic infants have been transfused with blood from our own donors, it seems likely that the difference is due to chance.

\section{Apparatus}

If any number of tests are to be done, it is an advantage to have specially designed apparatus. We have used perspex racks similar to those advised by Berlin (1947). In our comparison of the two techniques we found that to avoid labelling tubes in 
which cells were washed, blocks of translucent polystyrene plastic could be used; these were cylindrical, about $1 \frac{1}{8}$ in. diameter and $2 \frac{1}{4}$ in. long, with an axial hole to take a 20 S.W.G. brass wire. In each block five holes to carry precipitin tubes were drilled, each 2 in. long; the block was labelled with a letter, and each hole for a tube with a number. Labelling is best done with an ink containing Sudan Black B dissolved in a mixture of dichlorethylene and ethylene dichloride containing about 10 per cent Diakon (perspex) cement. The block fits a 50-ml. centrifuge bucket, and can be lifted out by the wire handle. The wall of the block is so thin that the column of red cells in the tube is easily seen, and after centrifuging the supernatant fluid can be sucked off and the cells resuspended without removing the tube from its holder (Plate $\mathbf{I} b$ ). An apparatus for removal of supernatant fluids was also devised; a suction pump is attached to a small Büchner flask, from which passes a rubber tube attached to a Pasteur pipette; the lumen of the rubber tube is closed by a glass bead, and by pinching the rubber tube to one side of the bead a channel is formed.

\section{Conclusion}

The capillary method has been so satisfactory in our hands that we no longer use the tube method in routine Rhesus typing, but keep it for testing for $\overrightarrow{\vec{\rho}}$ agglutinins in unknown sera and for titrating sera. The capillary method requires little skill, the result $\frac{C}{\sigma}$ usually being definite in fifteen minutes.

We are indebted to Dr. R. R. Race for drawing our attention to the method, to Dr. A. E. Mourant for supplying us with many of the antisera we have used,. to the originator of the method, Dr. Bruce Chown, $\overrightarrow{-}$ for his valuable advice, and to Mr. Tilman, assistant $\omega$ engineer to the hospital, for making apparatus to our design.

\section{REFERENCES}

Berlin, R. B. (1947). Amer. J. clin. Path., 17, 233. Chown, B., and Lewis, M. (1944). Amer. J. clin. Path., 14, Tech. Sect. 114.

Chown, B., and Lewis, M. (1946). Canad. med. Ass. J., 55, 66.

Chown, B., and Lewis, M. (1947). Personal communication. 204.

Diamond, L. K. (1947). Lecture in England, unpublished.

Hattersley, P. G. (1947). J. Lab. clin. Med., 32, 423.

Levine, P., Katzin, E. M., and Burnham, L.'(1941a). J. Amer. med. $\vec{\bullet}$ Ass., 116, 825.

Levine, P., Burnham, L., Katzin, E. M., and Vogel, P. (1941b). Amer. J. Obstet. Gynec., 42, 927.

Moloney, W. C. (1945). Brit. med. J., $2,916$.

Race, R. R. (1947). Personal communication.

\section{APPENDIX}

\section{NOTE ON THE WORKING OF POLYSTYRENE ROD}

BY

T. E. TILMAN

Assistant Engineer to the Hospital

The polystyrene plastic is brittle, and melts if machined carelessly or if it is not continuously cooled. Soap suds must be run over it continuously when machining or drilling. For turning, the rod is wrapped with a single layer of thick paper and held in a chuck and turned at 300 revolutions per minute. The tool must be of a good grade of tool steel, ground as for a side tool with nose slightly rounded off with a slight lip, and stoned to a fine edge ; ordinary grinding does not produce a smooth finish. Light cuts must be taken and coolant used $\frac{0}{7}$ continuously.

For drilling, a drilling machine or a lathe with $\delta$ instantaneous feed on a loose headstock must be used, since swarf chokes the flutes of the drill and leads 0 to local melting. The drill is ground as for brass and honed to a keen edge; it is fed lightly and cleared $\frac{7}{0}$ every $1 / 4$ in. to $3 / 8$ in., using a copious coolant.

As much material as possible should be left, $N$ especially where holes are close together. 